\title{
Sociale medier som læringsredskaber
}

\author{
Lill Ingstad, studielektor, Copenhagen Business School \\ Margrethe Smedegaard Mondahl, lektor, ph.d., Copenhagen Business School \\ Jonas Rasmussen, cand. ling. merc., undervisningsassistent og videnskabelig assistent \\ Lisbet Pals Svendsen, lektor, Copenhagen Business School
}

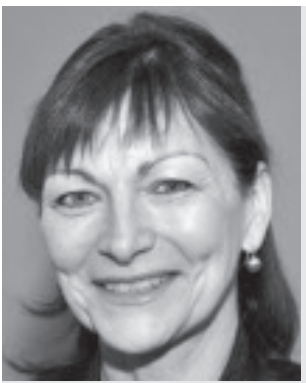

Lill Ingstad er Studielektor ved Copenhagen Business School, medlem af forskningsgruppen Uddannelsesforskning ved ISV (UFO). Forfatter og medforfatter til en række artikler om fremmedsprogstilegnelse, læring og sociale medier.

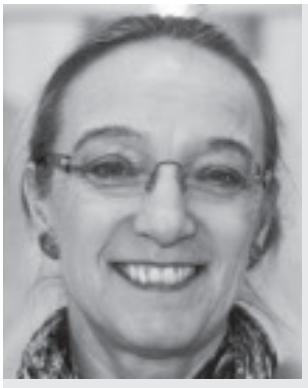

Margrethe Smedegaard Mondahl er lektor, ph.d. ved Copenhagen Business School, forskergruppeansvarlig for forskningsgruppen Uddannelsesforskning ved ISV (UFO). Forfatter og medforfatter til en række artikler om fremmedsprogstilegnelse, læring og sociale medier.

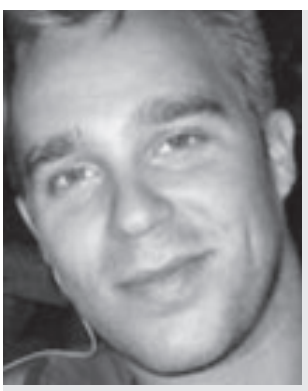

Jonas Rasmussen er cand. ling. merc. og undervisningsassistent og videnskabelig assistent i forskningsgruppen Uddannelsesforskning ved ISV (UFO). Forfatter og medforfatter til en række artikler om fremmedsprogstilegnelse, læring og sociale medier.

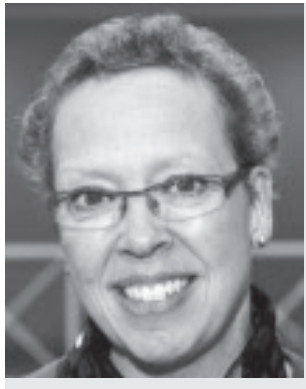

Lisbet Pals Svendsen er lektor ved Copenhagen Business School og medlem af forskningsgruppen Uddannelsesforskning ved ISV (UFO). Forfatter og medforfatter til en række artikler om fremmedsprogstilegnelse, læring og sociale medier.

\section{Reviewet artikel}

Kan sociale medier anvendes som loringsredskaber til stotte for sociale, kollaborative processer, der er udfordrende og motiverende, og som samtidig understotter (fremmedsprogs)tilegnelsen? Artiklen diskuterer eksempler på fagdidaktiske udfordringer $i$ sprogundervisningen på CBS med fokus på engelsk.

\section{Introduktion}

Dagens universitetsundervisere og forskere møder nye generationer af studerende, der er vant til at arbejde via digitale medier (Mondahl et al., 2009a), så vejen er banet for læringsmiljøer, der støtter nye metoder og redskaber til videndannelse. Nutidens studerende er vant til sociale medier som Twitter, LinkedIn og Facebook, og "recent studies suggest that the digital generation of students learn differently from the previous generation" og at de er "dependent on the web for accessing information and interacting with others" (Benson \& Avery, 2008).

Fremmedsprogskompetencer er efterspurgte i erhvervslivet, dog mest som dobbeltkompetence, og det stiller ændrede krav til formidlingen af viden og understøttelse af tilegnelsen. Her tænkes på pragmatiske virkemidler og kontekstuel forståelse, som bevirker, at sproglig viden ikke begrænser sig til grammatik men også refererer til en overordnet kommunikativ kompetence (Hymes, 1972), som er den ramme for interkulturel kommunikation, hvor den fremmedsproglige kompetence skal bringes i spil, f.eks. når medarbejderne kommunikerer i teams internt og eksternt i organisationen, både ansigt til ansigt og via sociale medier.

Artiklen diskuterer forholdet mellem kollaborativ og individuel læring, og hvordan sociale medier kan understøtte fælles og personlig viden via eksempler fra fire undervisningsforløb med dobbelt fokus: Engelsk som fremmedsprog $i$ kombination med viden om 'the business community' eller 'corporate communication'. Mange undervisningsaktiviteter kan her foregå som studenterdrevne problemløsningssituationer, f.eks. i 
forhold til krisekommunikation, målgruppetilpasning, intern/ekstern virksomhedskommunikation og formidling. Udfordringen er derfor at sætte den sproglige tilegnelsesproces $\mathrm{i}$ fokus. Men over for dette står, at mange, der skal tilegne sig sprog, opfatter kollaborativ læring som personligt udfordrende, og det vanskeliggør videndeling, peer-evaluering og åbenhed i forhold til læringsudbyttet.

\section{Baggrund}

Socialkonstruktivisme (Vygotsky, 1978), socialkonstruktionisme (Illeris, 2007), begrebet social læring som 'en mere legende indlæringsform' (Razmerita et al., 2005) og fremmedsprogstilegnelsesteorier, (Long, 1996, Mitchell \& Myles, 2004, Mondahl et al., 2009a), danner basis for etablering af en teoretisk ramme til forståelse af sproglig læring som tilegnelse af viden om sprog $i$ kontekst, dvs. sproglig viden forstået som lingvistisk, kulturel, diskursiv, pragmatisk og strategisk viden. Lærings- og tænkningsstile (Sternberg, 1997) inddrages, da de understøtter personalisering i en kollaborativ og personlig kontekst. At lære om fremmedsprogstilegnelse og international organisationskommunikation, udvide sin viden og mestre disse kompetencer er baseret på interaktion og på villighed til samarbejde over tid. Sproglig og kommunikativ kompetence er personlig og identitetsskabende, da sprog og sproglige handlinger anvendes til at give udtryk for personlige og/eller kollektive antagelser, holdninger og beslutninger.

Tilegnelsen af ny sproglig viden rummer både generel læring og mere specifik tilegnelse af fremmedsproget på proceduralt og deklarativt niveau og forudsætter, at det modtagne input er forståeligt (Mondahl et al., 2009b), ligesom tilegnelsen foregår ved forhandling af betydning (Hymes, 1972), hypotesedannelse og monitorering (Long, 2003).

Nye fællesskaber (emergent communities) (Lave \& Wenger, 1991) og feedback/forward feed (Hermansen, 2005) er centrale $i$ forhold til læringsresultaterne fra interaktive, legende og case-baserede læringssituationer. Mondahl \& Ingstad (2011) har vist, at case-baseret tilgang med tidlig interaktion i grupper faciliterer sproglig opgaveløsning i modsætning til mere traditionelle læringssituationer. Kreativitet er central i afkodning, interaktion og produktion af fremmedsprog og $\mathrm{i}$ den kognitive udfordring, som de studerende møder $i$ deres bestræbelser på at forhandle betydning. Sociale medier udfordrer og støtter $\mathrm{i}$ den forbindelse både individuel og gruppebaseret kreativitet, da grænserne for problemløsningsstrategierne er flydende: Nye applikationer kan skabes, nye måder til videndeling kan opfindes undervejs, og på den måde bliver de studerende deres egne undervisere. Figur 1 viser samspillet mellem elementerne i fremmedsprogstilegnelsen.

Figuren illustrerer den kollaborative lærings centrale betydning. Sproglig læring er inhærent, interperso-

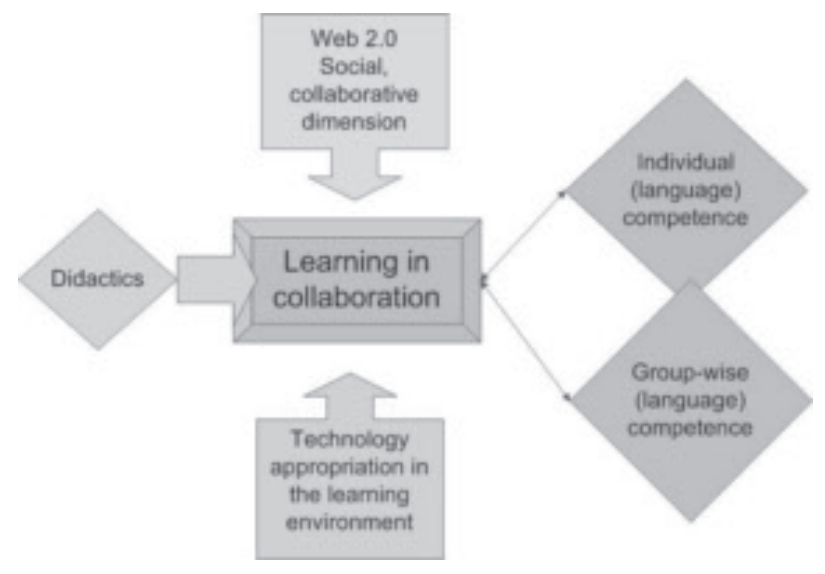

Figur 1: Elementer i universiter fremmedsprogstilegnelse i det 21. arrhundrede.

nel og baseret på betydningsforhandling af de enkelte ytringer og konteksten i læringsmiljøet, som i alle læringskontekster kan karakteriseres ved Hermansens begreber: Feedback/feedforward, habitus/refleksion og møje/overskud.

Motivation er en central drivkraft for læringen, og de studerende er nødt til at føle et behov for at kunne lykkes professionelt på fremmedsproget og opleve presset i den mundtlige kommunikationssituation, behovet for fagsprog og deres egne mindre succesfulde kommunikative møder for at blive motiveret til at tilegne sig de kompetencer, der kræves for at klare sig inden for særlige vidensområder som f.eks. krisekommunikation. Her er det væsentligt, at de studerendes samarbejde om problemløsningen faciliteres via f.eks. brug af wikier. Dette kan styrkes yderligere i en synkron IKT-platform, som omgående tracker ændringer og opdaterer ny viden, som deles i online communities (Duffy, 2007). Det har været centralt i designet af alle de fire kurser, som denne artikel omhandler. Kurserne »Intercultural Corporate Communication« (HA-IB), »Oral Communication« (BA EOK), »Business Communication« (BA IVK) og "Sprogrelaterede Markedsstudier» (CLM) er alle designet med kollaboration, problemløsning, videndeling og individuel feedback i centrum.

\section{Kollaborativ læring og Web 2.0}

Erfaringer viser, at kollaboration understøtter både generel læring og fremmedsprogslæring via verbalisering, argumentation og monitorering af output.Vellykketheden af især fremmedsprogslæringen hænger tæt sammen med interaktion, hvor læringen foregår som resultat af hypotesedannelse og hypotesetestning. Gøres dette på gruppeniveau, føler de studerende sig tilstrækkelig trygge til at udtrykke tvivl og viden og dermed forbedre deres kompetencer via problemløsningsaktiviteter.

Her fungerer underviserne som facilitatorer, giver feedback og monitorerer gruppernes arbejde og vurderer opgavebesvarelsernes kvalitet. Hvis de studerendes 
aktiviteter centrerer sig om f.eks. casearbejde, vil deres motivation og involvering betyde, at de tager ny viden ind, som vil lejre sig sådan, at den faciliterer dybdelæring og bevidst adgang til den opnåede viden.

En måde at etablere kollaborative scenarier på er at bruge Web 2.0 applikationer, der kan tilgås både som et nyt socialt medieredskab, som facilitator af nye former for interaktion og videndeling (Kirchner et al., 2008), som kilde til personlig information og videnstyringsværktøj og som didaktisk værktøj, der faciliterer interaktion og sociale processer. Web 2.0 applikationer omfatter f.eks. online chat forums, wikier og blogs, som gør videndeling enkel.Ved hjælp af Web 2.0 kan brugerne nemt udtrykke og dele meninger, 'tænke mens de skriver' samt høre andres mening og feedback.

Et eksempel er StudyBook platformen, som er en case-baseret IKT platform (se nedenfor) designet som et kollaborativt og personaliseret læringsmiljø, der integrerer blended learning strategier og Web 2.0 applikationer. StudyBook integrerer f.eks. et wiki-baseret samarbejds- og redigeringsmiljø. Blogs anvendes som læringslogs til støtte for læring og refleksion, hvorved læringslogs danner grundlag for personaliseret feedback på basis af individuelle problemer i forbindelse med besvarelsen af opgaver. De studerendes arbejde i StudyBook er organiseret som en flertrinsraket med et prædefineret flow, som kan tilpasses til de forskellige mål med læringsprocessen. De væsentligste trin er: 1) Arbejde med opgaver og opgavebesvarelser i wikis, 2) refleksion over læringsprocesserne via læringslogs og peer review samt 3) underviserens monitorering, vurdering og feedback.

\section{Fremmedsprogstilegnelsesprocesserne}

Som vist i figur 2 baserer fremmedsproglig viden sig på enten deklarativ eller procedural viden ${ }^{1}$. For at denne viden kan operationaliseres, og fordi læring er dynamisk og kontekstbaseret (Hermansen, 2005), er den konstante omstrukturering af viden nøglen til fremgang og skærpelse af kompetencer. Omstrukturering af sprogligt relateret viden foregår altid i direkte eller indirekte interaktion, fordi sprog er et kommunikationsredskab, og fordi ny indsigt skabes gennem betydningsforhandling (Kasper \& Roever, 2005).

Den studerende tester sine hypoteser på alle interaktionsniveauer - lingvistisk, diskursivt, pragmatisk, kulturelt og strategisk - og accepterer eller forkaster hypoteserne i forhold til, om kommunikationen forløber effektivt. Dermed restruktureres viden gennem dynamiske processer, som støtter eller forkaster kommunikationsstrategier, ny viden dannes på basis af eksisterende viden og får ny form og nye funktioner i den studerendes vidensspektrum, og fremmedsprogstilegnelsen sker som del af en social interaktion, som påvirkes af den studeredes kulturelle og kommunikative forståelse. Som følge af disse processer kan tidligere deklarativ viden omdannes til lettere tilgængelig og hurtigt anvendelig viden, ligesom procedural viden kan generaliseres og anvendes i nye situationer. Processerne foregår kontinuerligt, men for at strukturere dem og facilitere effektiv processering kræves der støtte fra omkringliggende læringsmiljøer, og her ligger en stor fagdidaktisk udfordring.

Set fra et didaktisk perspektiv betyder det, at facilitering af dynamiske processer kræver miljøer, der støtter betydningsforhandlingen, samarbejdet og videndeling, og dermed betyder det, at underviserne bliver nødt til at gentænke kursusstrukturer, progression, materialer $\mathrm{m} . \mathrm{m}$. for at drage den fulde nytte af potentialet ved IKT. F.eks. kan hentning af viden fra den studerendes 'videnbank' faciliteres ved at etablere processeringsmæssige 'kørebaner', som fører til korrekt og effektiv fremmedsprogsproduktion. IKT betyder også, at undervisernes rolle forandres fra den traditionelle underviserrolle til en mere coachende og mentorlignende rolle, idet IKT kun 'virker', hvis den enkelte studerende selv er aktiv og accepterer, at 'læring gør ondt' og er en del af en forandringsproces. Studerendes ofte normative tilgang til sprog og sproglig læring udfordres i højere grad af IKT baseret undervisning, som trækker på de medstuderendes kompetencer, end af lærerstyret spørgsmål/svar undervisning (Hermansen, 2005). Ændrede undervisningsformer og underviserroller stiller også krav om ændrede eksamensformer, som afspejler den reelle og den tilstræbte opfyldelse af læringsmål (alignment - Biggs, 2003).

Den underliggende hypotese bag brugen af IKT i fremmedsprogsundervisningen for voksne er altså, at det centrale læringspunkt ligger i krydsfeltet mellem motivation - behovet for at vide noget - og tilgængeligheden af relevant input for dannelsen af ny hentbar og anvendelig viden. Det er hér, at kollaboration og videndeling bliver centrale for fremskridt, og at umiddelbar feedback og monitorering af output belønner og faciliterer dannelsen af ny viden.

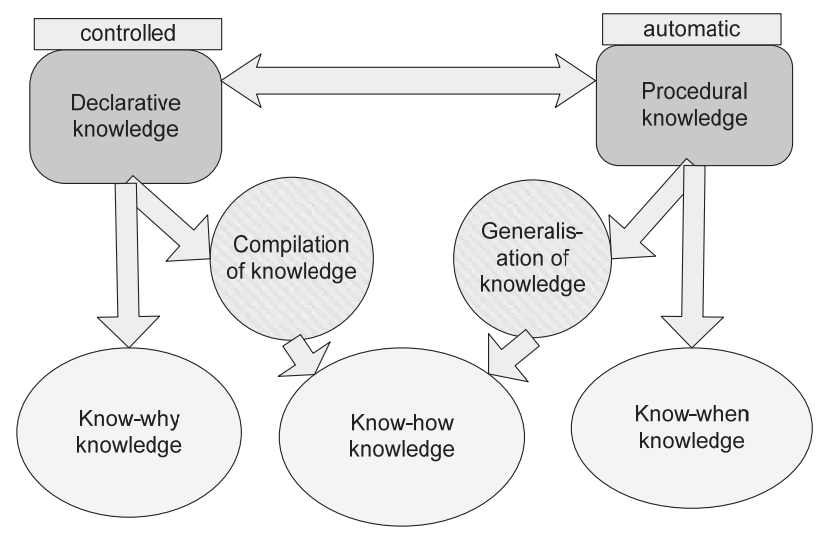

Figur 2: Den integrerede model for fremmedsprogstilegnelsesprocesser (Mondahl \& Jensen, 1996) 
Undersøgelser af fremmedsprogstilegnelse, som uddannelsesforskningsgruppen ved ISV/CBS har gennemført, viser, at kollaborativ læring bidrager til tilegnelsen af genanvendelige løsninger, når det drejer sig om pragmatisk, diskursiv og kulturel viden (Mondahl og Ingstad, 2011). Her støtter kollaboration og fælles problemløsning tilegnelsen, og succesraten bliver højere hos de studerende, som arbejder med wikis og lignende samarbejdsværktøjer. Når det derimod drejer sig om konkret lingvistisk kompetence - korrekthed og precision - opfattes denne som personlig og identitetsskabende, og fagfæller/medstuderende vil ikke kommentere eller rette. Der opstår en barriere mellem det fælles, rammeorienterede stof som genre, høflighed, talehandlinger og målgruppetilpasning og den identitetsorienterede kompetence, som opfattes som for privat til at andre kan gribe ind over for kompetencens kvalitet. Dette sidste punkt undersøges fremadrettet, men de fire forløb, som omtales nedenfor, har alle elementer af denne problemstilling. De fire forløb er medtaget i kronologisk rækkefølge, så de viser både et tidsmæssigt og et for underviserne lærings- og forskningsmæssigt forløb, der ikke er afsluttet i skrivende stund; IKT anvendes med forskelligt formål i de fire forløb, men set under et, rummer de et antal erfaringer, som kan bruges til at belyse hypotesen om den kollaborative lærings betydning for og indflydelse på fremmedsprogstilegnelsen. Skemaet sammenfatter de fire forløb mht. uddannelsesniveau, IKT platform og kursusformål.

\begin{tabular}{|l|l|l|l|}
\hline $\begin{array}{l}\text { Uddan- } \\
\text { nelse }\end{array}$ & $\begin{array}{l}\text { Seme- } \\
\text { ster }\end{array}$ & $\begin{array}{l}\text { Plat- } \\
\text { form }\end{array}$ & Formål \\
\hline BA (IVK) & 4. & $\begin{array}{l}\text { Study- } \\
\text { Book }\end{array}$ & $\begin{array}{l}\text { Produktion af vellyk- } \\
\text { ket skriftlig tekst på } \\
\text { engelsk. }\end{array}$ \\
\hline CLM & 2. & $\begin{array}{l}\text { Site- } \\
\text { Scape }\end{array}$ & $\begin{array}{l}\text { Professionalisering } \\
\text { af de studerendes } \\
\text { mundtlige kompe- } \\
\text { tence på engelsk. }\end{array}$ \\
\hline $\begin{array}{l}\text { BA } \\
\text { (EOK) }\end{array}$ & I. & $\begin{array}{l}\text { Study- } \\
\text { Book }\end{array}$ & $\begin{array}{l}\text { Styrkelse af mundtlig } \\
\text { præsentationskom- } \\
\text { petence og øget be- } \\
\text { vidsthed om retoriske } \\
\text { virkemidler. }\end{array}$ \\
\hline HA-IB & I. & Moodle & $\begin{array}{l}\text { Sammenligning mel- } \\
\text { lem Moodle og } \\
\text { dervisningsforløb i In- } \\
\text { tercultural Corporate } \\
\text { Communication. }\end{array}$ \\
\hline
\end{tabular}

\section{Forløb I}

Kursets fokus var at aktivere fremmedsproget på proceduralt niveau med fokus på pragmatiske, interkulturelle og strategiske aspekter. Det blev forudsat, at de studerende havde tilstrækkelig lingvistisk og diskursiv viden, der kunne aktiveres i en case-baseret, problemløsende proces.

Kursets og caseopgavernes kontekst var erhvervsrettet og omhandlede en virksomheds interne/eksterne kommunikation. Ud over at være proces- og problemløsningsorienterede var opgaverne produktorienterede, da de studerende skulle producere konkrete virkelighedsnære tekster. På baggrund af tidligere undersøgelser (Mondahl \& Ingstad, 2011) var det oplagt at bruge en samarbejdsorienteret didaktisk tilgang, da kurset fokuserede på det pragmatiske, kulturelle og strategiske niveau. Antagelsen var, at den elektroniske form ville motivere de studerende, og at de ville opnå dybere læring gennem den kollaborative og reflekterende tilgang.

Kurset lagde op til brug af wikis til tekstproduktion og blog-faciliteter, hvor de studerende kunne udveksle spørgsmål, refleksioner og dele viden, og til at de studerende lavede læringslogs for at kunne diskutere processer og problemløsning med underviser og medstuderende. Gruppernes tekster blev 'publiceret' online, og sammen med de studerendes læringslogs dannede de grundlag for feedback. Antagelsen om at de studerende ville modtage det nye didaktiske tiltag positivt blev dog ikke mødt, og i samtaler pegede de studerende på flere årsager. Nogle følte, at der var for mange forskellige elektroniske og sociale medier, som de skulle lære at bruge, og derfor bør det overvejes at skabe en fælles 'indgang' til forskellige elektroniske platforme. Nogle følte sig usikre over for underviserens nye rolle som facilitator - at man ikke bare kunne få den 'rigtige' løsning. Det tyder på, at det ikke kun er underviserne, der skal vænne sig til at spille en ny rolle som konsulent og facilitator, men at de studerende også skal omdefinere deres forventninger.

Et andet interessant aspekt var, at det især var de svageste og stærkeste studerende, der brugte platformen. Igen er der behov for undersøgelser, der kortlægger motivationen for kollaborativt arbejde og udbyttet af en individualiseret IKT platform for forskellige typer studerende med forskellige læringsstile. Det bør også overvejes, om der stadigvæk findes studerende, som ikke nødvendigvis er 'digital natives' trods vores forventninger herom.

Kursets formål blev kun delvis opnået af tre hovedårsager: De studerende var ikke villige til videndeling, de var usikre på den ændrede underviserrolle, og der var ikke tilstrækkelig alignment mellem kursets udformning og udprøvningen.

\section{Forløb II}

Kurset 'Sprogrelaterede Markedsstudier' havde to parallelle mål: Professionalisering af mundtlig kommunikationskompetence på engelsk og selvstændig tilegnelse af viden om markedsforhold $i$ et land, hvor engelsk er hovedsproget. Målet om professionalisering af den 
mundtlige kompetence sigter mod at bevidstgøre de studerende om vigtigheden af strategiske sproglige valg, som sikrer, at deres mundtlige kommunikation på engelsk lever op til niveau C1 i Common European Framework of Reference for Languages (Mondahl, Svendsen \& Rasmussen, 2010: 13), så de adskiller sig fra de mange brugere af engelsk, som er gode og kompetente men ikke professionelle brugere af engelsk som fremmedsprog.

Arbejdet foregik primært i 'traditionel' interaktion, fordi SiteScape ikke rummer synkrone faciliteter, men snarere fungerer som dokumentdelingsforum. Principperne for workshop-forløbet var kollaboration, således at ansvaret for et fagligt fornuftigt resultat af den enkelte workshop og for professionaliseringen af den mundtlige kompetence primært lå hos de studerende.

Det viste sig, at eksamensresultaterne for de studerende, der deltog i forløbet, blev bedre end for dem, der havde taget et forudgående mere traditionelt organiseret kursus, dvs. med en højere grad af underviserstyring. Karaktergennemsnittet var højere på såvel den 'faglige indholdsdel' som på den kommunikative kompetence. De to kurser blev udprøvet på samme måde gennem en skriftlig synopsis med mundtligt forsvar.

Efter første gennemløb blev der gennemført en spørgeskemabaseret evaluering og to fokusgruppeinterviews, så forløbet blev veldokumenteret, og på basis af svarene samt yderligere input, blev forløbet efterfølgende revideret til en version 2.0.

Formålet var at opnå en øget professionalisering af de studerendes mundtlige kompetence på engelsk, og eksamensresultaterne viste, at det i et vist omfang lykkedes. En yderligere læring af forløbet var, at underviseren undervejs fik en 'sidegevinst' i form af feedforward fra de aktive studerende, som foreslog forbedringer af forløbet, som efterfølgende er blevet implementeret.

\section{Forløb III}

I efteråret 2009 startede en ny uddannelse i engelsk og organisationskommunikation $(\mathrm{EOK})$ på CBS. Her blev det besluttet at bruge Web 2.0 baseret IKT i kurset Oral Communication for at styrke de kollaborative kompetencer i sprogtilegnelsen. Rammerne for kurset var forankret i et forskningsprojekt og havde til hensigt at undersøge: 1) Didaktiske problemstillinger, 2) metoder til at optimere motivation, 3) ændret dialog mellem underviser og studerende, 4) StudyBook - IKT-baseret sprogundervisning.

I evalueringen blev der spurgt til de studerendes viden om IKT, og her svarede $98 \%$, at de aldrig tidligere havde hørt om det! Dermed stilles der store krav til underviserne, når nye IKT platforme introduceres, til trods for at StudyBook platformen er udformet efter genkendelige sociale medier som Facebook og Twitter.

Kurset var opdelt i fællesforelæsninger efterfulgt af holdtimer, hvor de studerende skulle arbejde praktisk med forelæsningens teori. Der blev stillet opgaver, som krævede brug af wikier og blogs, og her viste det sig, at $40 \%$ brugte platformen til at diskutere opgaveløsninger og $31 \%$ til at diskutere indhold uden for undervisningen. Dog brugte hele $43 \%$ kun platformen til fildeling, hvorved det kollaborative element kompromitteres. For underviseren var den mest positive oplevelse den tættere kontakt særlig i forhold til blogs, da studerende selv kunne oprette dem eller indgå i dialog i underviserens blog. De studerende fik også gruppevis feedback i lukkede gruppefora. Dette blev modtaget meget positivt, da det for mange bevarede et element af individualisering. Endelig medvirkede det til at få aktiveret de 'stille piger', hvor den gode dialog blev faciliteret online.

StudyBook faciliterer kollaborativt arbejde som udgangspunkt for sproglig læring. Der er konstant fokus på dialog og interaktion, og underviseren/forskeren har mulighed for tracking, der kan bruges i forskningen og som evaluering af kurset og de studerendes individuelle udvikling. Platformen er fleksibel i forhold til brugen af applikationer, så de studerende kan skabe deres eget læringsmiljø og opstille parametre, der er vigtige i læringsprocessen. Det er hensigten at fortsætte med StudyBook for at være på forkant med nye didaktiske tiltag, der kan være fremmende $i$ forhold til inddragelsen af IKT i fremmedsprogtilegnelse, da dette også er relevant for bl.a. virksomheders medarbejderkompetenceudvikling.

Formålet var en styrkelse af mundtlig præsentationskompetence og øget bevidsthed om retoriske virkemidler. En 'sidegevinst' ved brugen af StudyBook var den øgede dialog mellem underviseren og de 'stille piger' og internt mellem de studerende. Der var også en højere grad af sprogligt relateret aktivitet ud over dokumentdeling på platformen.

\section{Forløb IV}

Hensigten var at sammenligne to IKT platforme (SiteScape og Moodle) for at identificere didaktiske muligheder for at skabe effektiv læring. De studerendes arbejde var fokuseret på henholdsvis sproglig (pragmatisk) kompetence samt metaviden om dette og på teoretisk viden om interkulturel organisationskommunikation. Tilgangen var case- og problemorienteret. Interaktionen i gruppearbejdet var præget af indholdsdiskussioner snarere end af løsninger af sproglige udfordringer. Dog var opgaveløsningerne påvirket af diskussion af sproglige problemstillinger, således at den sproglige dimension fremstod som en del af de studerendes erhvervede kompetencer.

Kurset var rettet mod ikke-sprogstuderende, og derfor måtte underviserne forholde sig til sociale mediers muligheder for at bringe sproget i fokus, så de kunne adressere den sproglige kernefaglighed, og hvad den betyder for studerende, der har brug for dobbeltkom- 
petence, og dermed motivere de studerende til at interessere sig for den sproglige dimension. Baseret på tidligere undersøgelser (Mondahl \& Ingstad, 2011) var antagelsen, at udfordringerne i den kollaborative proces i forhold til den personlige tilegnelsesoplevelse ville blive centrale, herunder hvordan personalisering kan understøttes uden at blive grænseoverskridende. Det blev antaget, at sociale medier ville spille en positiv rolle i sprogtilegnelse, og at underviseridentiteten ville være udsat for nye udfordringer.

Det var centralt for kursets didaktik at teste nye metoder til at supportere voksne indlærere. Der var særligt fokus på pragmatik og kontekstuel forståelse. Tilegnelsesmæssigt var det tilstræbte 'learning outcome' af 'know-how' typen (jf. figur 2), det vil sige muligheden for at gennemføre problemløsningsorienterede opgaver for derigennem at opnå en tilgængelig form for viden, der kunne anvendes effektivt i kommunikationssituationer.

Kurset testede en demoversion af Moodle platformen, som muliggjorde arbejde i wikis. De studerende var imidlertid ikke særligt motiverede for denne arbejdsform. De anvendte i stedet platformen til fildeling. Dette resultat står i stærk kontrast til forskningsresultaterne fra forsøget med StudyBook (forløb III), og kan derfor relatere sig til typen og opbygningen af platformen.

Evalueringsresultater og fokusgruppeinterviews (CBS Learning Lab 2009) viste, at de studerende oplevede underviserrollen under forandring uden at de nødvendigvis opfattede deres egen rolle som forandret - ansvaret for egen læring var ikke fremtrædende, men det var derimod ønsket om personaliserede, online platforme og om underviseren som sparringspartner. Netop derfor er samarbejde og videndeling i forhold til sproglig kompetence og professionalisering et vanskeligt felt, idet studerende oplever at lingvistisk kompetence er personlig, identitetsskabende og derfor vanskelig for dem selv og andre at adressere $\mathrm{i}$ forhold til at ændre/omlære allerede eksisterende viden.

Formålet var en sammenligning mellem IKT platformene Moodle og SiteScape. Resultaterne viser, at de studerende primært opfattede Moodle platformen som et fildelingsværktøj på linje med SiteScape og ikke som en samarbejdsplatform. Det betyder, at der må stilles krav til en IKT læringsplatform i form af bl.a. applikationer, som understøtter den kollaborative dimension i både skriftlighed og mundtlighed, således at der opnås en højere grad af dybdelæring, refleksion og mulighed for genanvendelse af erhvervet viden.

\section{Konklusioner}

Som nævnt står universitetsundervisere og forskere over for nye generationer af studerende, der er vant til at arbejde via digitale medier, og dermed er vejen banet for et nyt læringsmiljø på universiteterne. Ud fra denne viden arbejdes der hen imod en samarbejdsbetonet didaktisk tilgang til læring, herunder tilegnelsen af professionel sproglig kompetence.

Antagelserne bag de beskrevne forløb var at sociale medier er bedre egnet til at understøtte sociale og kollaborative processer end ikke-samarbejdsbetonede medier, at IKT platforme kan fastholde både fælles og individuel viden og styrke vidensforarbejdningen og dermed resultatet af læringsprocessen.

De beskrevne forløb var baseret på en socialkonstruktivistisk og en socialkonstruktionistisk tilgang og antagelsen om at læring er en forandringsproces, og at bevidste, kognitive strategier og motivation er afgørende for succesraten.

Baseret på de erfaringer, som er skildret i denne artikel, kan vi sige, at for at facilitere effektiv læring for studerende i det 21. århundrede, som for flertallets vedkommende er resultatorienterede snarere end akademisk orienterede, er det centralt, at der så effektivt som muligt kan tilføjes ny viden til allerede eksisterende viden. Især StudyBook platformen viste sig at facilitere brugbart input, betydningsforhandling, output og monitorering, opmærksomhed på tænkningsstile og personaliseret/individualiseret viden. Herudover faciliterede StudyBook tilegnelsen af sproglig viden $\mathrm{i}$ en erhvervsmæssig sammenhæng og styrkede progressionen i forløbet gennem at tydeliggøre læringsmålene. Forsøgene viste også, at de didaktiske krav, som undervisning ved hjælp af IKT og sociale medier stiller, er markant anderledes end de krav, som mere traditionel undervisning stiller. Dvs. at der bør arbejdes med både underviserroller, studenterroller og kompatibilitet i 'kendte' opgaver anvendt i 'nye' medier.

\section{Referencer}

Benson,V. and B. Avery (2008). „Embedding Web 2.0 Strategies in Learning and Teaching", I: Miltiadis Lytras P.O.D.P. (Ed.). Web 2.0: The Business Model, USA: Springer Science and Business Media.

Biggs, John (2003). Teaching for Quality Learning at University. Maidenhead, UK: Open University Press, McGraw-Hill Education, $2^{\text {nd }}$ edition.

Duffy, P. (2007). "Engaging the YouTube Google-Eyed Generation: Strategies for Using Web 2.0 in Teaching and Learning«, I: European Conference on ELearning, ECEL 2007, Copenhagen, Denmark, pp. 173-182.

Hermansen, M. (2005). Relearning, Copenhagen: Danish University of Education Press and CBS Press.

Hymes, Dell (1972). "Models of the Interaction of Language and Social Life«. I: J. Gumperz \& D. Hymes (Eds.). Directions in Sociolinguistics: The Ethnography of Communication (pp.35-71). New York: Holt, Rhinehart \& Winston.

Illeris, K. (2007). How We Learn.Learning and Non-learning in School and Beyond, New York: Routledge.

Kasper, G., \& Roever, C. (2005). "Pragmatics in second language learning «. I: E. Hinkel (Ed.). Handbook of Research in Second Language Learning and Teaching (pp.317-334). Mahwah, NJ: Erlbaum.

Lave, J. \& Wenger, E. (1991). Situated Learning - Legitimate Peripheral Participation, UK: Cambridge University Press.

Long, Michael (1996). "The Role of the Linguistic Environment in Second Language Acquisition«. I: Ritchie, W.C. \& T. K. Bahtia 
(eds.). Handbook of Second Language Acquisition, San Diego:Academic Press, pp.413-468).

Long, Michael (2003). "An Introduction to Second Language Acquisition Research" (eds.). Michael H. Long, Catherine J Doughty, Handbook of Second Language Acquisition, Blackwell Publishing Ltd.

Mitchell, R. and F. Myles (2004). Second Language Learning Theories 2nd edition, New York: Oxford University Press

Mondahl, M., L. Razmerita \& J. Rasmussen (2009a). "Social Software, Thinking Styles, Personalization and Case-based Foreign Language Learning: The Quest for new Pedagogical Models in Higher Education". Electronic Journal of E-Learning, (under udgivelse). 20096.

Mondahl, M., L. Razmerita \& J. Rasmussen (2009b). »Web 2.0Applications, Collaboration and Cognitive Processes in Case-Based Foreign Language Learning", I: Visioning and Engineering the Knowledge Society - A Web Science Perspective. Lecture Notes in Computer Science, Subseries: Lecture Notes in Artificial Intelligence, Vol. 5736. Lytras, M.D.; Damiani, E.; Carroll, J.M.; Tennyson, R.D.; Avison, D.; Naeve, A.; Dale, A.; Lefrere, P.; Tan, F.; Sipior, J.;Vossen, G. (Eds.). SpringerLink.

Mondahl, M., L. Svendsen \& J. Rasmussen (2010). Professional Oral Communication in English. Handelshøjskolens Forlag.

Mondahl, M. and K. A. Jensen, (1993). "Lexical Search Strategies in Translation, Meta, vol. 41, pp.97-114.
Mondahl, M., L. Ingstad (2011) (under udgivelse). "Elektronisk case i sprogundervisning", Sprogforum.

Pedersen, Michael (2010). Moodle test evaluation, Summary Report, B.Sc.-IB students, 2nd Quarter 2009. CBS Learning Lab.

Razmerita L., G. Gouarderes \& E. Comte (2005). Ontology-based User Modeling and e-Portfolio Grid Learning Services, Applied Artificial Intelligence Journal, vol. 19, pp.905-931.

Sprogkernen (2009). www.sprogkernen.dk.

Sternberg, R. J. (1997). Successful intelligence. New York: Plume.

Vygotsky, L.S. (1978). Mind in the society - The development of higher psychological processes, Cambridge, MA: Harvard University Press.

\section{Noter}

1 Skellet mellem procedural og deklarativ viden er centralt for intersprogsbegrebet. Dette begreb gør det muligt at fokusere på sprogtilegnelsesprocessen som en dynamisk størrelse, der imidlertid næppe nogensinde når den indfødte sprogbrugers kompetenceniceau. 